\title{
Mucilaginous species of Thalassiosira Cleve emend. Hasle (Diatomeae) in South Brazilian waters
}

\author{
Luciano Felício Fernandes ${ }^{1,2}$ and Edinara Katiussia Frassão-Santos ${ }^{1}$
}

Recebido em 23/10/2009. Aceito em 3/12/2010

\begin{abstract}
RESUMO
(Espécies mucilaginosas de Thalassiosira Cleve emend. Hasle (Diatomeae) em águas do Sul do Brasil). Thalassiosira é um gênero intensivamente estudado desde 1970, sendo abundante e bem representado em diferentes ambientes marinhos. A despeito da extensão costeira do Brasil, $8.500 \mathrm{Km}$, poucos trabalhos tem sido realizados para investigar a morfologia de Thalassiosira utilizando técnicas de microscopia eletrônica. Neste trabalho, as espécies mucilaginosas Thalassiosira diporocyclus, T. mala e T. minuscula foram examinadas em microscópios ótico e eletrônico, com base em material coletado em águas costeiras do sul do Brasil (Paraná, Santa Catarina e Rio Grande do Sul), para registrar a variabilidade morfológica das frústulas. Alguns resultados inéditos relacionados à estrutura da cribra e do cíngulo são mostrados T. mala possui aréola central com menos poros cribrais do que as aréolas da região marginal. Além disso, as medidas do diâmetro valvar de T. diporocyclus e T. minuscula são ampliadas em relação ao previamente registrado. As duas espécies são novos registros para águas brasileiras, e T. diporocyclus é citação nova para o Oceano Atlântico Sul Ocidental.
\end{abstract}

Palavras-chave: diatomáceas, Thalassiosira, fitoplâncton taxonomia, Paraná

\begin{abstract}
(Mucilaginous species of Thalassiosira Cleve emend. Hasle (Diatomeae) in South Brazilian waters). Thalassiosira is a large diatom genus intensively studied since the 1970s, being well represented in diverse marine environments worldwide. Despite the long Brazilian coastline, about $8,500 \mathrm{~km}$, few taxonomic works have been performed to investigate the morphology of Thalassiosira species using electron microscope techniques. In this paper the mucilaginous species Thalassiosira diporocyclus, T. mala and T. minuscula were examined in light and electron microscopes, based on material gathered from South Brazilian waters, to record their frustule morphological variability. Some unrecorded findings related to the cribra structure and the cingulum bands are shown. T. mala has central areolae bearing fewer cribral pores than those located in the marginal region. In addition, the valve metrics of T. diporocyclus and T. minuscula are extended in relation to that reported in the current literature. The two species are new records for Brazilian waters, and T. diporocyclus is a new one in the Western Atlantic Ocean.
\end{abstract}

Key words: diatom, Thalassiosira, taxonomy, phytoplankton, Paraná

\section{Introduction}

Since the seminal studies of Helmcke \& Krieger (1953; 1954) and Hasle and Fryxell (Hasle 1972a; Hasle \& Syvertsen 1997 and references therein) using electron microscopy to unveil the fine structure of valve and cingulum of Thalassiosira Cleve, much knowledge has been gathered about genus morphology. For the time being, the genus Thalassiosira encompasses more than 150 species, and many more species surely are to be described in diverse marine areas worldwide.
Surprisingly, the extensive Brazilian coastline, about $8,500 \mathrm{~km}$, has been relatively poorly studied regarding the taxonomy of Thalassiosira. Even in South Brazil, where many investigations focusing on diatom taxonomy have been carried out, only a few works are available for Thalassiosira using electron microscopy (Torgan \& Santos 2006, 2007; Garcia \& Odebrecht 2099a, 2009b). Previous contributions relied on light microscope observations, generating basic surveys and checklists (Moreira Filho et al. 1990). These authors listed 12 species and 2 varieties in South Brazil. Further, Procopiak et al. (2006) reviewed the

\footnotetext{
1 Universidade Federal do Paraná, Centro Politécnico, Departamento de Botânica, Setor de Ciências Biológicas, Curitiba, PR, Brazil

2 Author for correspondence: 1ff@ufpr.br
} 
studies on the diatoms of Paraná coastal waters spanning from 1918 to 2005, and recorded 20 species and 5 varieties, all of them identified through light microscopy. More recently, Garcia \& Odebrecht (2009b) recorded 17 species in Rio Grande Sul.

Ecological studies in the shelf waters off Paraná state, South Brazil, pointed out the significant contribution of Thalassiosira to the phytoplankton (Brandini \& Fernandes 1996; Brandini et al. 1997; 2007; Fernandes \& Brandini 2004). Net plankton material of Paraná and additional samples from Santa Catarina and Rio Grande do Sul states were made available to start a survey on Thalassiosira species, examining their composition and frustule morphology using electron microscopy.

The high species richness found in the study area is related with oceanographic features such as the dominance of Shelf Water, a water mass flowing southwestward resulting from mixing of the warm, salty and nutrient poor Tropical Water and the Coastal Water, nutrient rich and affected by land drainage. During summer, the deeper cold South Atlantic Central Water (SACW) mix with the Tropical Water over the shelf, eventually reaching the photic zone and promoting phytoplankton growth (Brandini 2006). In austral autumn and winter, the nutrient rich colder Subantarctic Water, flowing northeastward carried by the Malvinas Current, mixes with the Shelf Water and transports northward temperate diatom species from Argentina and Uruguay (Fernandes \& Brandini 2004). Thus far, about 58 Thalassiosira species were reported for Argentinean waters, some of them abundant in the plankton (Lange 1985; Vouilloud 2003). The role of the Malvinas Current in periodically changing the species richness along the Paraná coast is evident. Indeed, species typical of cold water like Thalassiosira nodulolineata, T. poroseriata and T. tumida have been detected in previous ecological studies (Fernandes \& Brandini 2004), all of them regular constituents of Argentinean plankton (Lange 1985; Olguin et al. 2006). Our sampling grid covered all the seasonal oceanographic variability described above, in the Paraná shelf waters.

In this first report we describe three abundant small species of Thalassiosira from South Brazilian shelf waters, aiming to record their morphological variability and to compare their metric data with material from other marine environments based on the current literature.

\section{Material and methods}

Field samples were collected monthly from August 1997 to March 1999 in five stations located 10-15km apart along the Paraná coastal shelf $\left(25^{\circ} 42^{\prime}-25^{\circ} 50^{\prime} \mathrm{S}\right.$; $\left.48^{\circ} 27^{\prime}-48^{\circ} 55^{\prime} \mathrm{W}\right)$, with water depth between 10 and 50 meters. Vertical net hauls were carried out from bottom to surface in each station using a plankton net of $40 \mu \mathrm{m}$ mesh size. Formaldehyde was immediately added to the samples, reaching $2 \%$ final concentration. Additional samples were examined from material collected in Florianópolis $\left(27^{\circ} 37^{\prime} 51.97^{\prime \prime}\right.$; $\left.{ }^{\circ} 22^{\prime 2} 25.83^{\prime \prime W}\right)$, Santa Catarina state, and in shelf waters off Rio Grande do Sul state (30¹2'40.10"S; $\left.49^{\circ} 8^{\prime} 13.91^{\prime \prime} \mathrm{W}\right)$ during the Brazilian Antarctic Expedition PROANTAR XIII in 1994.

In the laboratory, samples were submitted to the Hasle \& Fryxell (1970) technique for cleaning the frustules and examination in light and electron microscopes. About 280 permanent slides for light microscope (LM) were prepared with Naphrax ( $\mathrm{r}=1.74)$ as mounting medium. Scanning electron microscopy (SEM) preparations were made by pipeting some drops of samples directly over the aluminum stubs, and brought to a JEOL JSM 6360LV microscope for observations at $10-15 \mathrm{Kv}$ acceleration voltages and a working distance of 8 millimeters. Samples containing high numbers of valves were prepared for transmission electron microscope (TEM) examination. A small drop was put in nickel mesh 200 grids covered with Formvar and Carbon, and air dried. The JEOL JEM 1200EXII microscope was used at $80 \mathrm{Kv}$ acceleration voltage.

Species identifications were validated by consulting the references indicated below the taxon's name. Terminology followed Hasle \& Syvertsen (1997), complemented by Round et al. (1990) and Barber \& Haworth (1981).

\section{Results}

1. Thalassiosira diporocyclus Hasle, Norw. J. Bot., v. 19, p. 113, Fig. 25-45, 1972b.

(Fig. 1-23 and Tab.1)

Hasle (1972b), Rivera (1981), Hallegraeff (1984), Herzig \& Fryxell (1986), Licea (1992), Takano (1990), Miyahara et al. (1996), Hasle \& Syvertsen (1997), Fryxell \& Hasle (2003).

Light Microscope: Cells solitary or in small colonies of 3-4 cells united by abundant mucilage (Fig. 1). Lighter strands can be observed inside the mucilage leaving the cell margin (Fig. 1). Valve circular, slightly convex; valvar diameter 14-32 $\mu \mathrm{m}$. Valvar surface areolate; areolae loculate very small, disposed in parallel striae and packed in sectors, that is, fasciculate (sensu Johansen \& Fryxell, 1985). Areolae only visible under phase contrast illumination. Two rings of fultoportulae are present (Fig. 2-8). Fultoportulae of marginal ring more spaced at the half associated with the rimoportula than at the opposite margin, where they are closer spaced (Fig. 2-5). One single slightly eccentric fultoportula (Fig. 4, 7). Rimoportula marginal, inserted between the fultoportulae of the marginal ring (Fig. 2, 5). Small sized valves bear a lower number of fultoportulae in both rings (Fig. 6-8).

Electron Microscope: Valve circular and convex, slightly concave in the center. Areolae arranged in fascicles (Fig. 9); areola hexagonal and occluded by 3-10 cribral pores (mostly 7-8) (Fig. 12, 15); 30-32 areolae in $10 \mu \mathrm{m}$ in the center and 

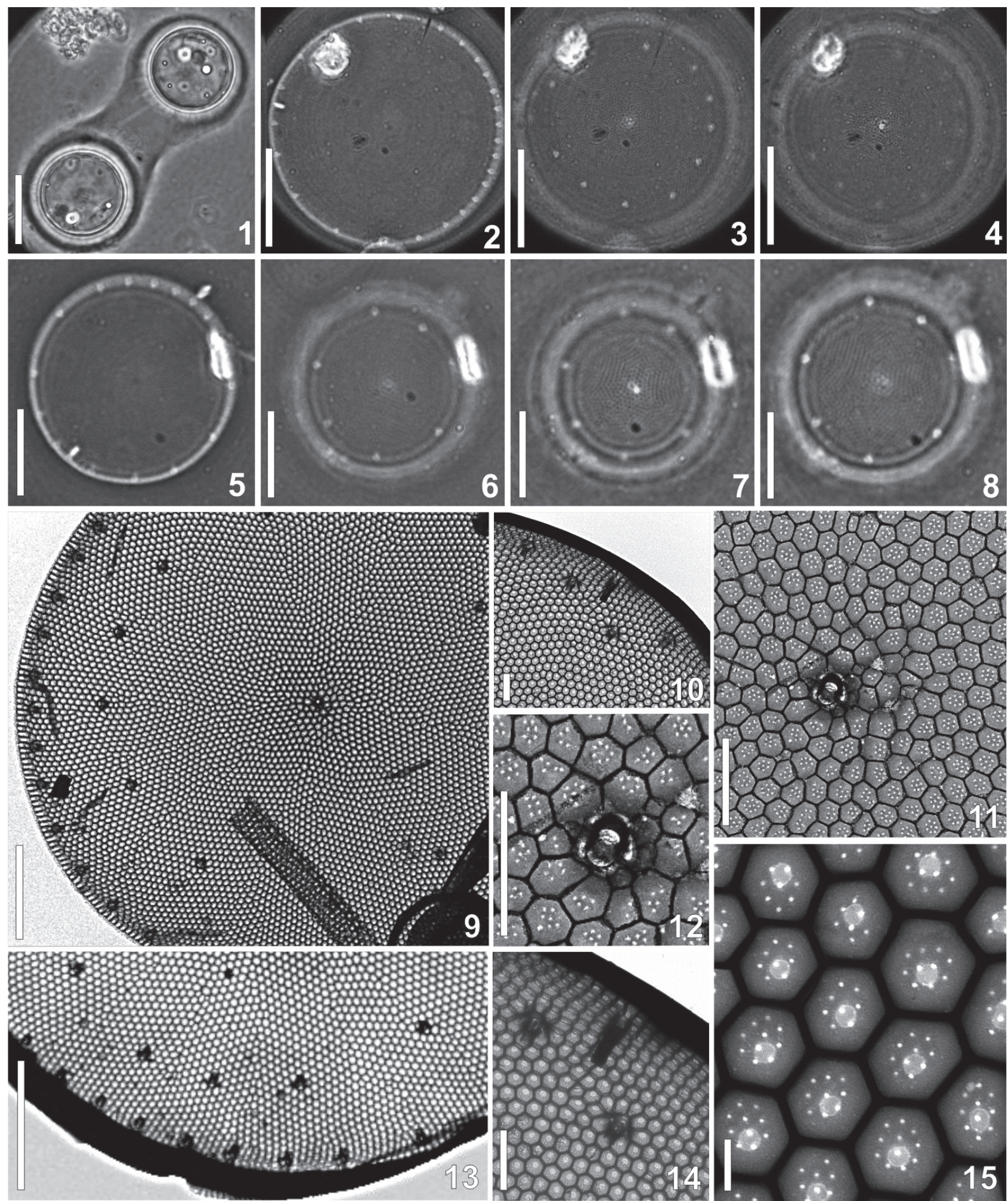

Figures 1-15. Thalassiosira diporocyclus Hasle, valve views in LM (1-8) and TEM (9-15). 1. Preserved cells embedded in mucilage, also with thin strands; 2-8. Phase contrast, valves in different foci. 9. Fasciculate striae pattern. Note two rows of fultoportulae and the central one; 11-12. Central area showing areolae structure and fultoportulae bearing four satellite pores; 13-14. Disposition of fultoportulae rings on the valve face. 15. Detail of hexagonal areolae. Cribral pores are aligned in a circle with a central pore. Scale bars: Figure $1=10 \mu \mathrm{m}$; Figures $2-8=10 \mu \mathrm{m}$; Figure $9=5 \mu \mathrm{m}$; Figures $10-12=1 \mu \mathrm{m}, 14=1 \mu \mathrm{m}$; Figure $13=2$ $\mu \mathrm{m}$; Figure $15=0.2 \mu \mathrm{m}$. 

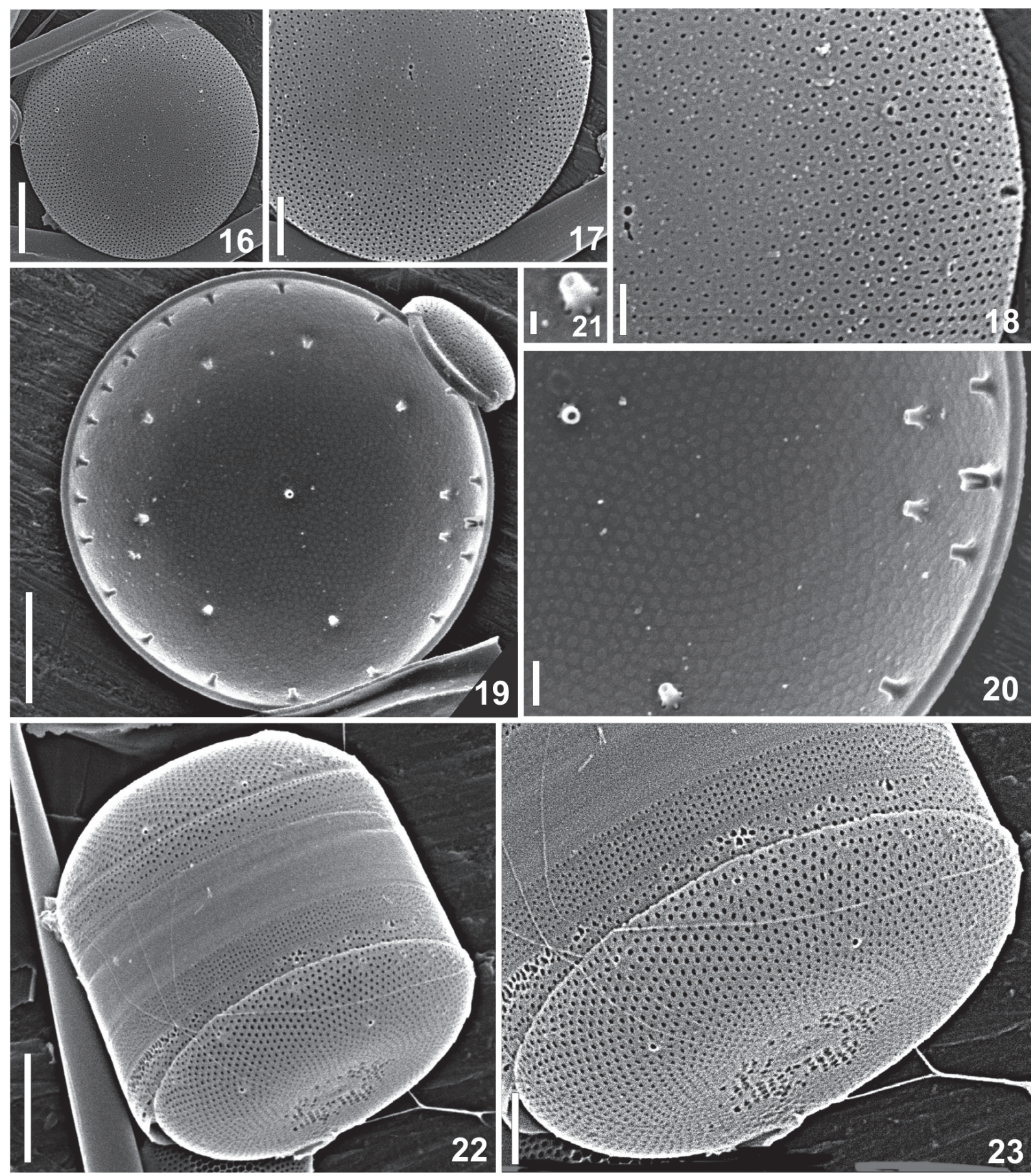

Figures 16-23. Thalassiosira diporocyclus Hasle, SEM. 16-17. General pattern of areolae. 18. External view, illustrating the external openings of fultoportulae and marginal rimoportula. Note thickened rim around the fultoportula aperture. 19-20. Internal valve views, evidencing the structure of rimoportula and fultoportula. 21. Detail of marginal fultoportula. 22-23. Frustule in girdle view. Mucilage strands are viewed passing through the fultoportulae. The bands of cingulum have tranverse rows of poroids. Scale bars: Figures 16, 19, $22=5 \mu \mathrm{m}$; Figures 17, $23=2 \mu \mathrm{m}$; Figures 18, $20=1 \mu \mathrm{m}$; Figure $21=0,2 \mu \mathrm{m}$.

$39-41$ in $10 \mu \mathrm{m}$ in the margin. At the center there is one single fultoportula (Fig. 12, 18-20). Externally, the fultoportula opens in a circular aperture slightly raised (Fig. 18); internally, short tubular projections are surrounded by four satellite pores (Fig. 20-21). Fultoportulae are arranged in two rings (Fig. 9-10, 13, 19). The first one is submarginal, having 6-15 fultoportulae. The second ring is marginal, with 12-29 fultoportulae, more densely packed in the half of the valve opposite to the rimoportula (Fig. 19). The rimoportula is located on the valve margin, between the marginal smaller fultoportulae (Fig. 14, 20). The external aperture of rimoportula is elongate while the internal fissure is surrounded by silica thickenings, and somewhat projected with respect to the base. Cingulum bearing 3-4 bands (Fig. 22-23). The valvocopula and the 
Table 1. Comparative valve measurements for $T$. diporocyclus recorded from the literature and the present study.

\begin{tabular}{|c|c|c|c|c|}
\hline & Valvar Diameter $(\mathrm{mm})$ & $\begin{array}{c}\text { Areolae in } \\
10 \mu \mathrm{m} \text { (center) }\end{array}$ & $\begin{array}{c}\text { Areolae in } \\
10 \mu \mathrm{m} \text { (margin) }\end{array}$ & Striae Pattern \\
\hline Hasle (1972) & $12.5-19$ & $20-28$ & - & Sectors* \\
\hline Rivera (1981), & $12-18$ & $24-31$ & - & Radial \\
\hline Hallegraeff (1984) & $16-20$ & $26-28$ & - & Fasciculate \\
\hline Herzig \& Fryxell (1986) & 15 & $\geq 30$ & - & Radial $^{*}$ \\
\hline Licea (1990) & $15-24$ & $26-28$ & $32-36$ & - \\
\hline Takano (1990) & $12-24$ & $20-28$ & - & - \\
\hline Miyahara et al. (1996) & $25-45.5$ & 30 & - & Fasciculate \\
\hline Hasle \& Syvertsen (1997) & $12-24$ & $24-31$ & - & Fasciculate \\
\hline Fryxell \& Hasle (2003) & $12-24$ & $24-31$ & - & Fasciculate \\
\hline This study & $14-32$ & $30-32$ & $39-41$ & Fasciculate \\
\hline
\end{tabular}

*: Described as radial or forming sectors, but author's illustrations show fasciculate pattern sensu Johansen \& Fryxell (1985).

adjacent band are entirely pierced by small poroids in vertical rows; poroids larger in the valvocopula. Third and fourth bands do not possess visible ornamentation.

Geographic distribution: Atlantic Ocean $\left(19^{\circ} 48^{\prime} \mathrm{N}\right.$, $18^{\circ} 06^{\prime} \mathrm{W} ; 33^{\circ} 11^{\prime} \mathrm{S}, 17^{\circ} 52,5^{\prime} \mathrm{E}$, record of A. M. Sampayo in Hasle 1972b); Gulf of Mexico $\left(30^{\circ} 07,2^{\prime} \mathrm{N}, 85^{\circ} 46,5^{\prime} \mathrm{W}\right.$; $24^{\circ} 43,5^{\prime} \mathrm{N}, 87^{\circ} 20.0^{\prime} \mathrm{W}$, Hasle 1972b; Licea 1992); Indian Ocean (Hasle 1972b); Australia (Hallegraeff 1984); Japan (Takano 1990 and Miyahara et al. 1996); and c. $40^{\circ} \mathrm{N}$ (Atlantic) $-40^{\circ} \mathrm{S}$ (Pacific) (Fryxell \& Hasle 2003).

Material examined: Paraná and Santa Catarina. Abundant in November and December off Paraná coast; temperature $21-26^{\circ} \mathrm{C}$, salinity $34.0-36.5$.

2. Thalassiosira minuscula Krasske, Arch. Hydrobiol., v. 38, p. 262, pr. 5, Fig. 4-6, 1941.

(Fig. 24-47 and Tab. 2)

Synonym: Thalassiosira monoporocyclus Hasle, Norw. J. Bot., v. 19, p. 129, Fig. 46-60, 1972b.

Hasle (1972b), Rivera (1981), Hallegraeff (1984), Mahood et al. (1986), Ferrario \& Sar (1988), HernándezBecerril \& Tápia-Peña (1995), Aké-Castillo et al. (1999), Sar et al. (2002).

Light Microscope: Cells cylindrical with many parietal ellipsoid chloroplasts. The cells are enclosed in circular pads of mucilage joined together to form large colonies (Fig. 24-28). Valve circular, valve diameter 16-23 $\mu \mathrm{m}$. Surface areolated; areolae barely perceptible even in phase contrast microscopy. Striae pattern fasciculate, almost indistinct (Fig. 29-32). One ring of fultoportulae is present at the marginal area (Fig. 29). Rimoportula is large and elongate, marginal, but discreetly displaced towards the valve center in relation to the fultoportulae ring (Fig. 30-31). One or two fultoportulae are placed nearer the rimoportula than the others (Fig 31). One single fultoportula can be hardly seen at the valve center (Fig 31).

Electron Microscope: Valves circular; valve surface almost flat (Fig. 33). Striae radial, packed in fascicles (Fig. 34-35), 30-40 areoale in $10 \mu \mathrm{m}$ in the center, and $36-45$ in $10 \mu \mathrm{m}$ in the valve margin. Areolae hexagonal occluded by 6-10 (mostly 6-8) cribral pores (Fig. 36-37). A slightly eccentric fultoportula appears in the valve center (Fig. 36, 40-41). A single ring of 13 in fig 41 16-23 fultoportulae is placed marginally on the valve (Fig. 41). Each fultoportula has external circular opening encircled by a small hyaline area (Fig. 42). Internally, it possesses a short tube supported by four satellital pores (Fig. 37, 4547). At the border between mantle and surface the single rimoportula occurs. It is projected internally, bearing an elongate-rimmed fissure (Fig. 38-39, 43-45). The outer opening is subrectangular, larger than the fultoportulae (Fig. 42). No external tube was recorded but in one single valve (Fig. 38). Close to the rimoportula there are two, sometimes one, fultoportulae (Fig. 34, 42-45). Cingulum has open valvocopula covered with transverse rows of poroids (Fig. 42). The second band is ligulated; the other possible bands were not studied.

Geographic distribution: Brazil (Rio Grande do Sul, Garcia \& Odebrecht 2009a; Baía de Guaratuba, Paraná, Lehmkuhl et al. 2010); Argentina (Ferrario \& Galván 1989); Province of Chubut (Ferrario \& Sar 1988); Balneario Las Grutas (Sar 1996); Balnearios Santa Teresita, Mar de Ajó, Nueva Atlantis, Pinamar and Villa Gesel - Buenos Aires (Sar et al. 2001); Gulf of San Matías (Sar et al. 2002); Atlantic Ocean (Portugal - A. M. Sampayo in Hasle 1972b); Atlantic - c. $59-58^{\circ} \mathrm{N}$ (Fryxell \& Hasle 2003); Pacific - Chile (Fryxell \& Hasle 2003); Chile, Talcahuano (ca. $37^{\circ} \mathrm{S}, 73^{\circ} \mathrm{W}$, Hasle 1972b); Mexico - Gulf of Tehuantepec (Aké-Castillo et al. 1999); San Francisco Bay (Mahood et al. 1986); Gulf of California (Hernández-Becerril \& Tápia-Peña 1995); Pacific 

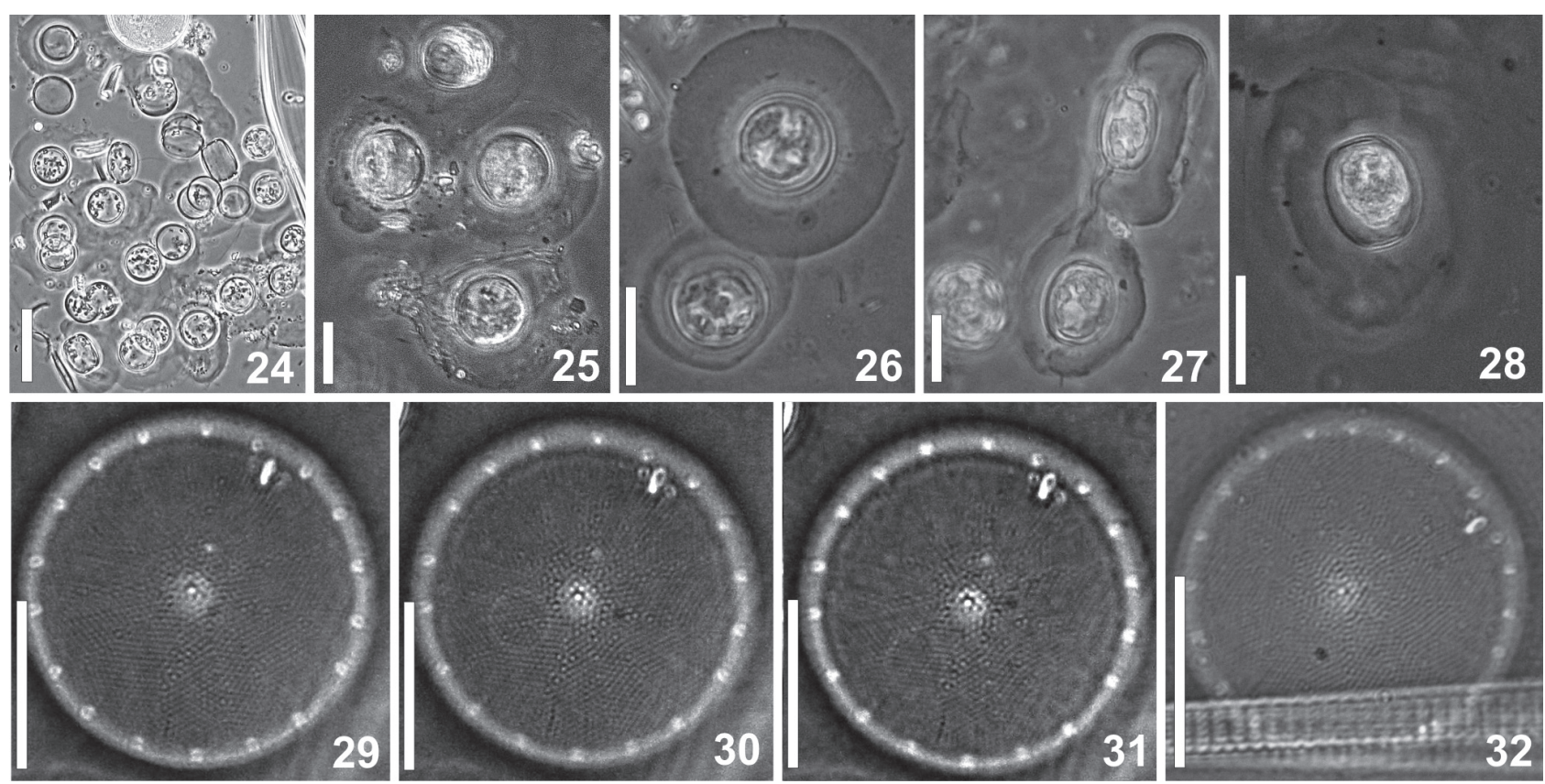

Figures 24-32. Thalassiosira minuscula Krasske, LM phase contrast. 24-28. Preserved cells in dense mucilage colonies. 29-32. Valves in different focal planes. Two fultoportulae are close to the rimoportula. Scale bars: Figures $24=20 \mu \mathrm{m}$; Figures $25-32=10 \mu \mathrm{m}$.

$\left(28^{\circ} 00^{\prime} \mathrm{N}, 112^{\circ} 17,5^{\prime} \mathrm{W} ; 6^{\circ} 45,5^{\prime} \mathrm{S}, 80^{\circ} 18^{\prime} \mathrm{W}\right.$ and $14^{\circ} 58,5^{\prime} \mathrm{S}$, $77^{\circ} 17^{\prime} \mathrm{W}$, Hasle 1972b) and Australia (Hallegraeff 1984).

Material examined: Paraná, Santa Catarina and Rio Grande do Sul. Abundant in November and December in Paraná coast; temperature $21-26^{\circ} \mathrm{C}$, salinity $34.0-36.5$.

3. Thalassiosira mala Takano, Bull. Tokai Reg. Fish. Res. Lab., v. 42, p. 1, pr. 1, figs 1-8, 1965

(Fig. 48-69 and Tab. 3)

Takano (1976; 1979), Rivera (1981), Hallegraeff (1984), Licea (1992), Hernández-Becerril et al. (1995), Aké-Castilho et al. (1999), Sar et al. (2002), Fryxell \& Hasle (2003).

Light Microscope: Cells joined in dense mucilaginous colonies. Valves circular, valvar diameter 3-12 $\mu \mathrm{m}$. Valvar surface areolated; areolae faintly noticeable (Fig. 48-49). One marginal ring of fultoportulae. An almost undistinguishable fultoportula is located at the middle distance between the margin and the center, and always aligned with the rimoportula. Rimoportula larger than the fultoportulae and marginal placed between the ring of fultoportulae (Fig. 48).

Electron Microscope: Valves circular; valve surface flat, bearing pentagonal and hexagonal areolae arranged in eccentric striae pattern (Fig. 50-52). Areolae composed of 2-16 cribral pores, with maximal number near the margin, gradually diminishing towards the valve center (Fig. 53-55, 58). In smaller valves the number of pores reaches its minimum (Fig. 53). Many areolae have irregular foramen aperture, from small to large, that is, lacking any silica membrane (Fig. 59-60). On the mantle there are 10-30 fultoportulae disposed in a marginal ring (Fig. 56, 63-64). Their number decreases with the reduction of the valve diameter (Fig. 50-52, 63-64). Each fultoportula bears a circular external opening (Fig. 66); and the internal one is a short tube surrounded by four satellite pores (Fig. 53, 67-69). In the same line of the fultoportulae ring there is the rimoportula, which opens externally by means of a circular aperture, larger than the foramina of areolae (Fig. 62, 66). Internally, there is an elongate fissure bordered by silica thickenings, slightly more raised than the fultoportulae (Fig. 62). Between the valve margin and the center, and separated from the rimoportula by 2-6 areolae, up to eight in larger valves, there is a fultoportula. It is surrounded by three satellital pores, each one having parentheses-like thickenings (Fig. 55, 58, 68-69). External aperture is rounded, slightly larger than the areolae (Fig. 66).

Geographic distribution: Argentina - Gulf of San Matías (Sar et al. 2002); Trinidade (Fryxell \& Hasle 2003); Mexico (Licea 1992); Mexico - Gulf of Mexico (Takano 1976); Gulf of Tehuantepec (Aké-Castillo et al. 1999); Gulf of California - Temperate and Subtropical regions (Hernández-Becerril et al. 1995); Africa (Fryxell \& Hasle 2003); Australia (Hallegraeff 1984; Fryxell \& Hasle 2003) and Japan (Takano 1976, 1979; Fryxell \& Hasle 2003).

Material examined: Paraná, Santa Catarina and Rio Grande do Sul. Abundant in November and December in Paraná coast; temperature $21-26^{\circ} \mathrm{C}$, salinity $34.0-36.5$. 

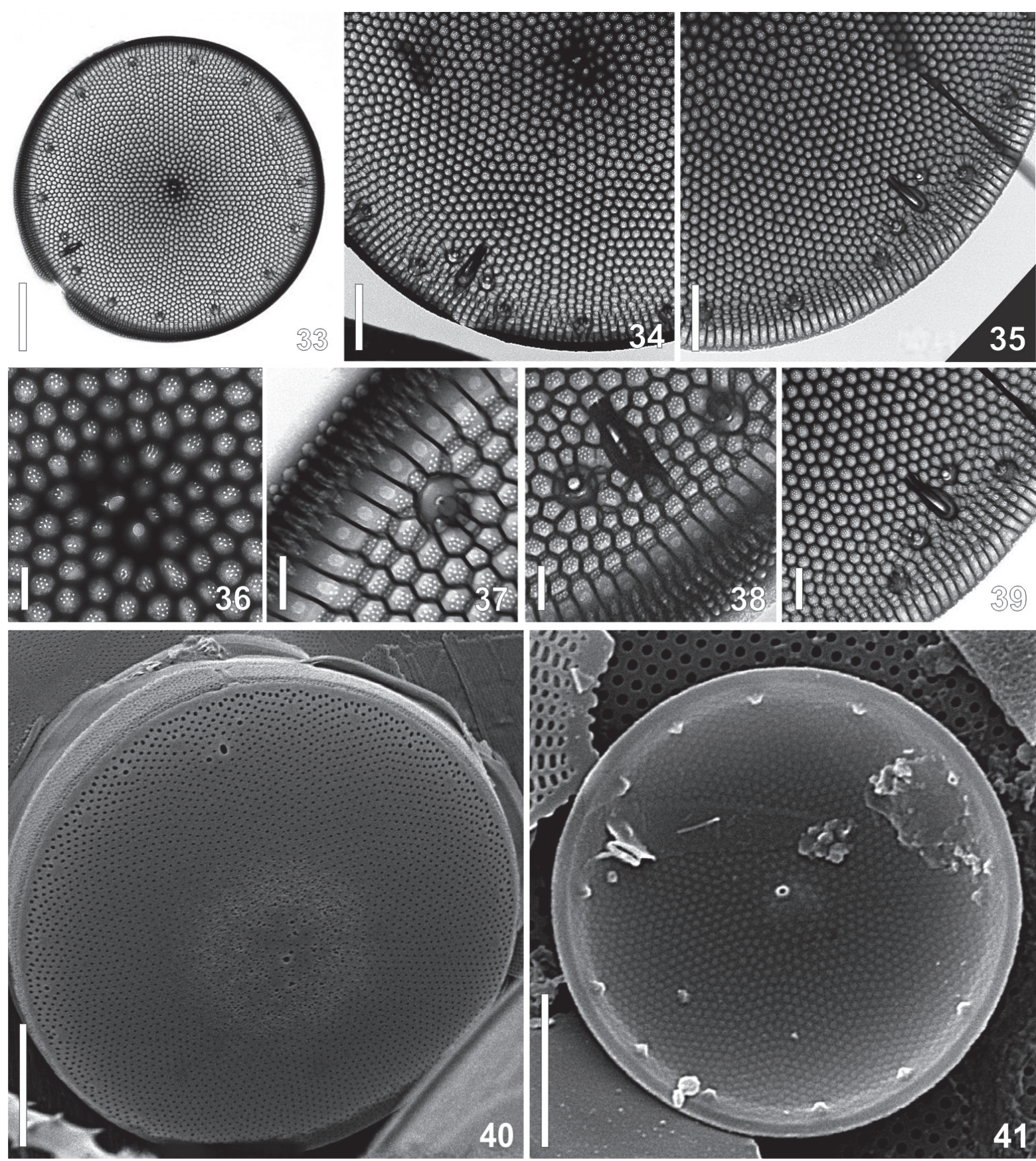

Figures 33-41. Thalassiosira minuscula Krasske, transmission (33-39) and scanning (40-41) electron microscopes. 33. Overall valve view displaying fasciculate pattern. 34-35. Valve details, rimoportula and its closer placed fultoportulae. 36. Central fultoportula. Areolae have cribra arranged in one single circle surrounding a central pore. 37. Detail of margin and fultoportula. 38. Marginal rimoportula and its tube, to which two fultoportulae are associated. 39. Internal structure of rimoportula. 40. Overall external valve view. Note external opening of rimoportula. 41. Internal view of valve. Note central fultoportula. Scale bars: Figures $33-35$ $=2 \mu \mathrm{m}$; Figures $36-38=0.5 \mu \mathrm{m}$; Figure $39=1 \mu \mathrm{m}$; Figures $40-41=5 \mu \mathrm{m}$.

\section{Discussion}

The material studied did not reveal too much discrepancy regarding valve morphology when compared to data from the literature (Tables 1, 2, 3). T. diporocyclus and T. minuscula had the number of marginal areolae in $10 \mu \mathrm{m}$ increased from 32-36 to 39-41, and from 32-39 to 36-45, respectively (Hasle 1972b; Rivera 1981). T. mala showed the greatest variability in the number of cribral pores per areola, especially the small frustules, in which the central areolae have as few as two pores while the marginal region $8-16$ pores. The pictures consulted in the literature listed in Table 3 did not allow us to record the number and possible shifting of cribral pores in T. mala from other world regions.

When viewed in light microscope T. diporocyclus, newly recorded for the Western Atlantic Ocean, may be easily 

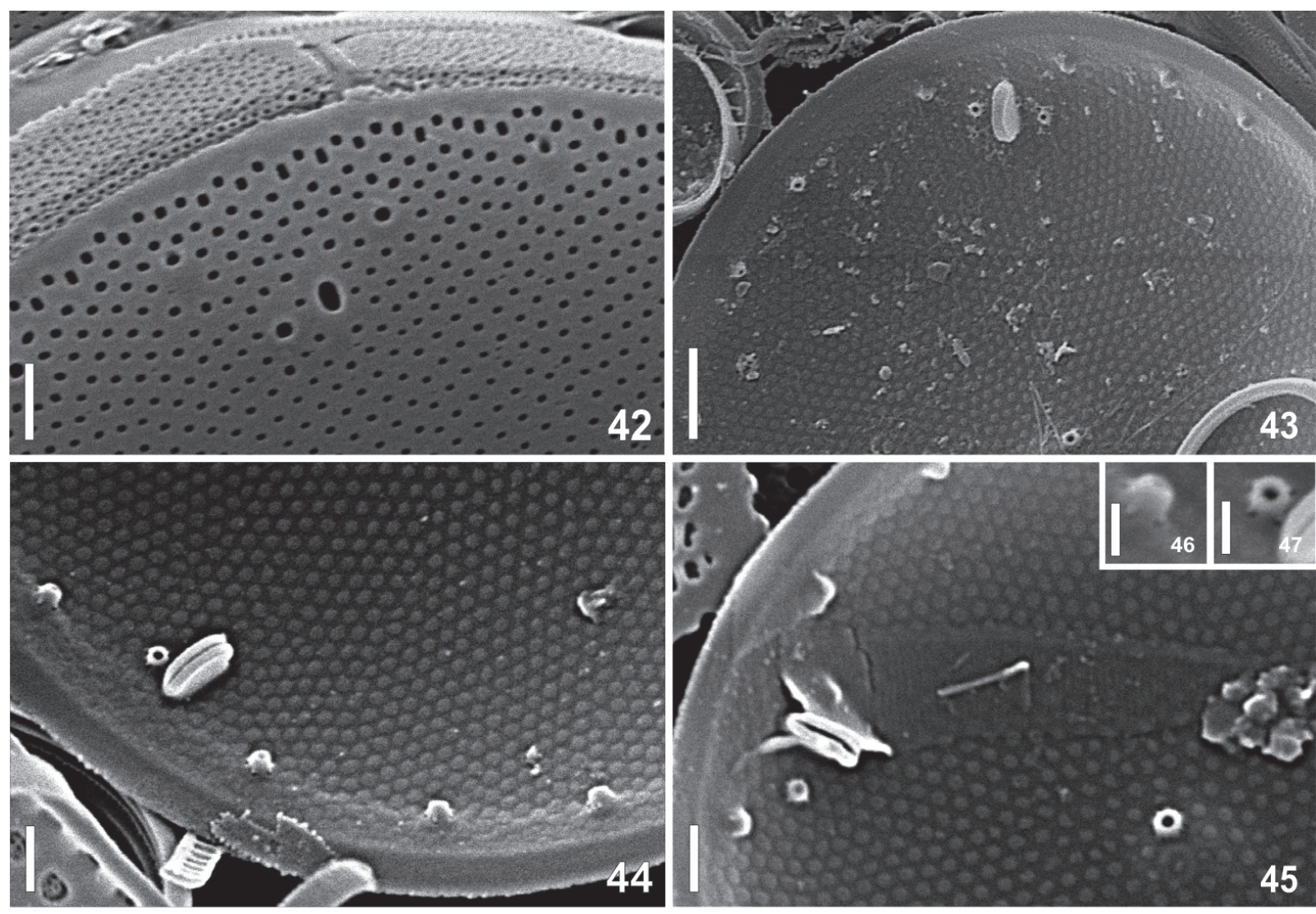

Figures 42-47. Thalassiosira minuscula Krasske, SEM. 42. Rimoportula. Circular openings of fultoportulae are encircled by a hyaline area. 43-45. Different morphologies of rimoportula in internal view. 46-47. Details of fultoportulae at inner side. Scale bars: Figures $42,44-45=1 \mu \mathrm{m}$; Figure $43=2 \mu \mathrm{m} ;$ Figures $46-47=0.5 \mu \mathrm{m}$.

Table 2. Comparative valve measurements for T. minuscula recorded from the literature and the present study.

\begin{tabular}{|c|c|c|c|c|}
\hline & Valvar Diameter $(\mathrm{mm})$ & $\begin{array}{c}\text { Areolae in } \\
10 \mu \mathrm{m} \text { (center) }\end{array}$ & $\begin{array}{c}\text { Areolae in } \\
10 \mu \mathrm{m} \text { (margin) }\end{array}$ & Striae Pattern \\
\hline Hasle (1972) & $16-20$ & $\geq 30$ & - & Sectors* \\
\hline Rivera (1981) & $10-27.5$ & $32-48$ & - & Radial \\
\hline Hallegraeff (1984) & $17-23$ & $32-37$ & - & Sectors* \\
\hline Mahood et al. (1986) & $10-20$ & 30 & - & Radial $^{*}$ \\
\hline Ferrario \& Sar (1988) & $16-21.5$ & $40-48$ & - & Fasciculate \\
\hline Hernández-Becerril et al. (1995) & $18-21$ & 29-32 & - & Radial $^{*}$ \\
\hline Aké-Castillo et al. (1999) & 8.5 & 50 & - & Fasciculate \\
\hline Sar et al. (2002) & $10-32$ & 32 & $32-36$ & Fasciculate \\
\hline This study & $16-23$ & $30-40$ & $36-45$ & Fasciculate \\
\hline
\end{tabular}

*: Described as forming sectors or radial, but author’s illustrations show fasciculate pattern sensu Johansen \& Fryxell (1985).

confounded with Thalassiosira subtilis (Ostenfeld) Gran. This species has the rimoportula slightly displaced to the valve center regarding the marginal ring of fultoportulae (see illustrations of Hasle 1972b and Hallegraeff 1984), that is, not aligned as in T. diporocyclus. There is a higher number of fultoportulae scattered on the valve surface of T. subtilis than in $T$. diporocyclus, in which they are organized in two rings (Hasle 1972b; this study). On the other hand, this distinction is weakened as the valve size diminishes for the areolae of $T$. subtilis become arranged in rings. In such a circumstance, rimoportula position is the best criterion to differentiate the two species. Additionally, the external opening of T. subtilis is elongate and gives rise to a tube, while subrectangular and, as far is known, lacking external tube, in T. diporocyclus. Comparing T. diporocyclus with T. minuscula, the latter has one ring of marginal fultoportulae, not two like in T. diporocyclus; 

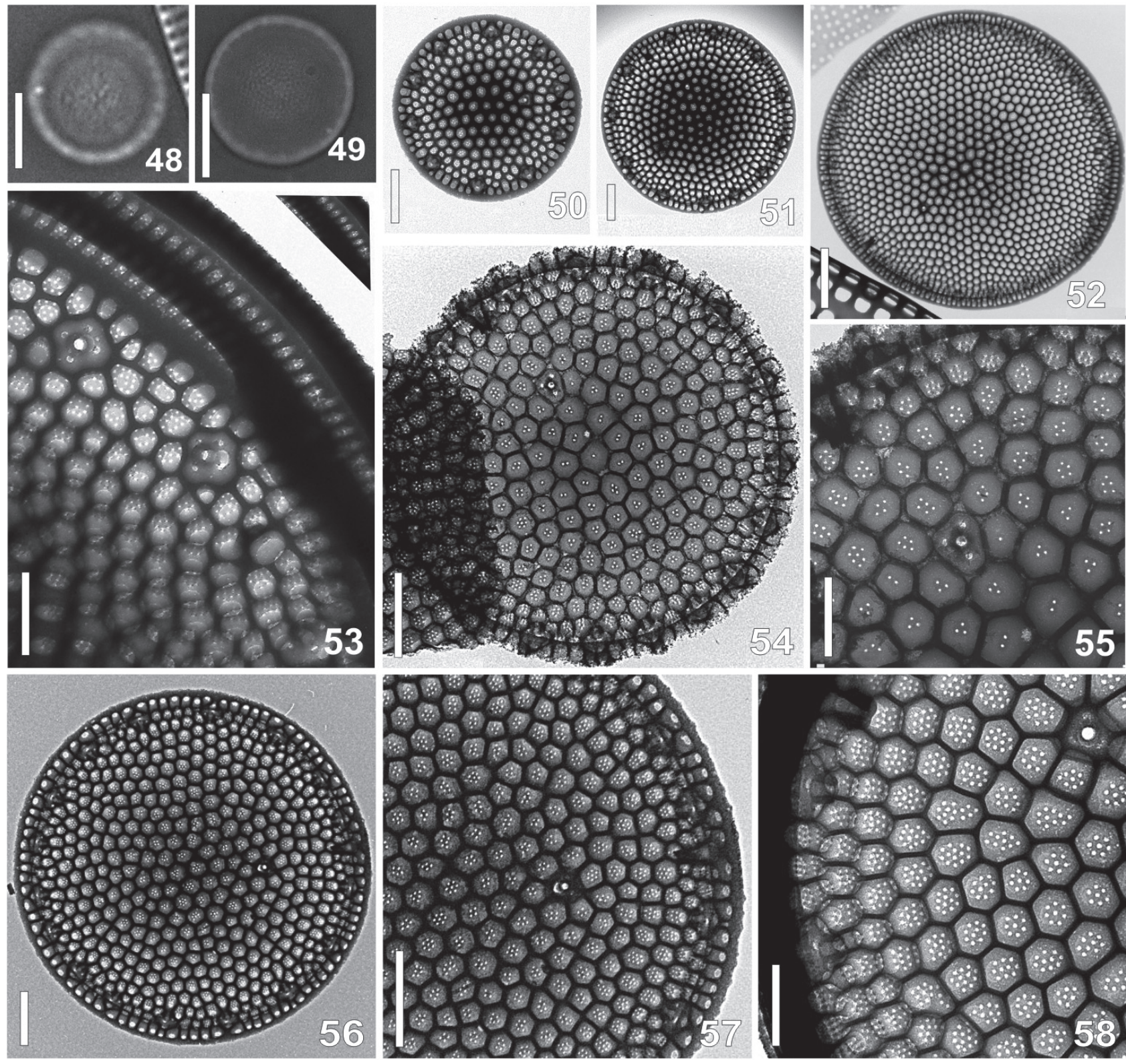

Figures 48-58. Thalassiosira mala Takano, LM (48-49) and TEM (50-58). 48-49. Rimoportula is viewed as a small bright point at the margin. 50-52. Valves with distinct diameters and morphologies. Number of fultoportulae diminishes as valve size decreases. 53. Marginal fultoportulae composed of four satellites each. 54-55. Small sized valve. Note the low number of cribral pores per areola. Submarginal fultoportula has three satellites. 56-58. Large sized valve. Number of fultoportula is higher than in small valves. Scale bars: Figures $48-49=5 \mu \mathrm{m}$; Figures 53, 55, $58=0.5 \mu \mathrm{m}$; Figures 50-51, 54, 56-57 =1 $\mu \mathrm{m}$; Figure $52=2 \mu \mathrm{m}$.

and there is one or two fultoportulae closely associated with the rimoportula of T. minuscula, a feature not observed in $T$. diporocyclus. Rivera (1981) documented a long external tube in the rimoportula of T. minuscula. In our material, the tube was detected only in one valve, illustrated in Figure 38.

T. diporocyclus and T. mala are new records for Brazilian waters, even though they were abundant during the study off Parana (F. P. Brandini, unpublished data) besides T. minuscula. Their small dimensions could explain the absence of previous records, but $T$. diporocyclus and $T$. minuscula occur in dense gelatinous colonies, which should make them easy to detect during routine microscope counting or identification. Previous researchers collected material only in shallow waters off Paraná, mainly in estuarine areas, where T. diporocyclus and T. mala were not detected (Fernandes \& Brandini 2004, Procopiak et al. 2006, Lehmkuhl et al., 2010). On the other hand, lugol preserved samples may destroy the mucilage, and the species would be named or counted as "unidentified centrics" or "Thalassiosira spp.". (e.g. Brandini \& Fernandes 1996; Fernandes \& Brandini 2004). Once these small diatoms have been reliably described, their identification during routine plankton surveys will be greatly improved and increase the resolution of ecologically oriented projects. 

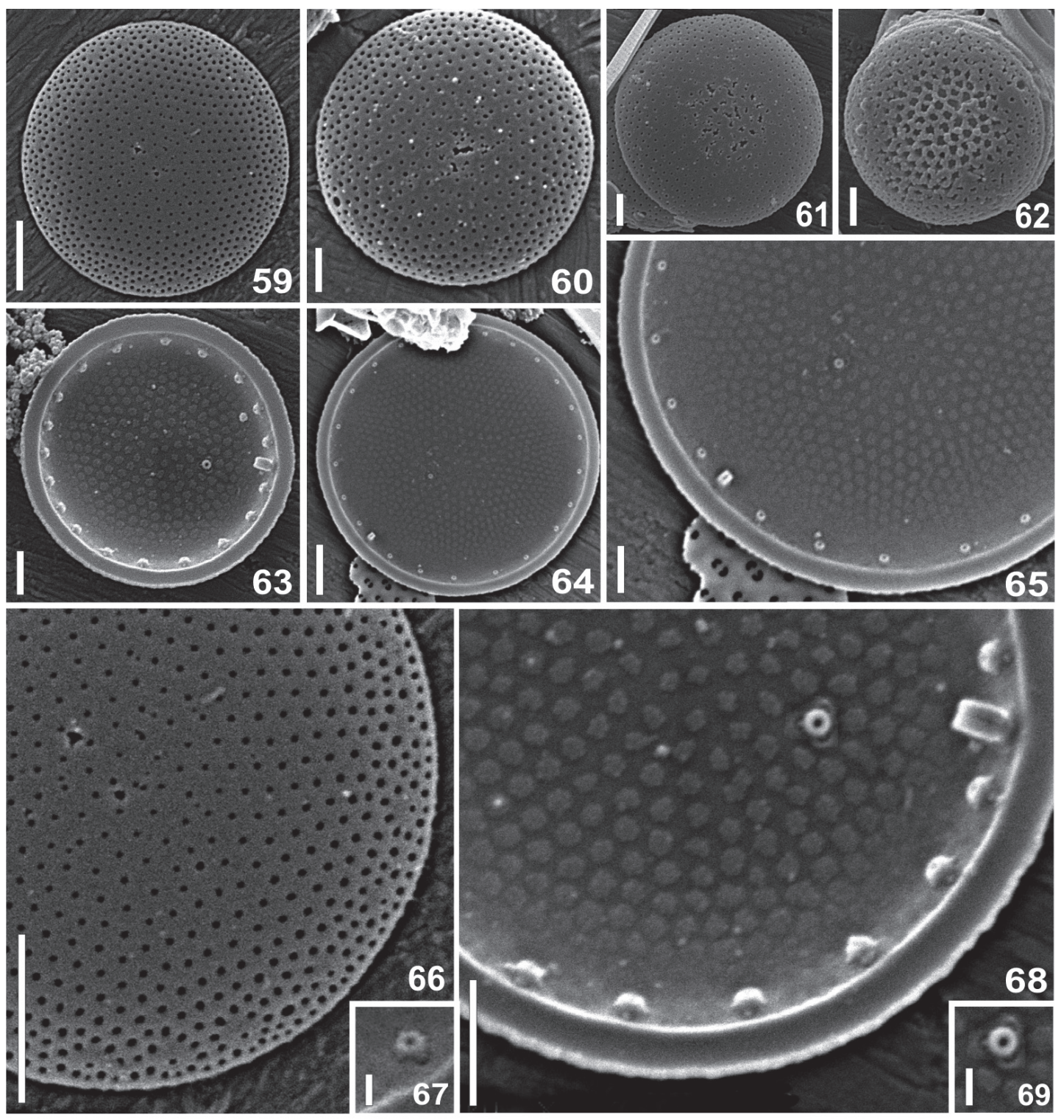

Figures 59-69. Thalassiosira mala Takano, SEM. 59-62. Overall external views of valves in progressive size reduction. 63. Small valve in internal view. Submarginal fultoportula is placed four areolae apart from rimoportula. 64-65. Large valve. 66. External view, illustrating marginal ring of fultoportulae, each one having circular opening surrounded by a hyaline area. Rimoportula and solitary fultoportula on the valve face are also illustrated. 67. Detail of marginal fultoportula. 68. Inner valve view, showing fultoportula and rimoportula structures. 69 . Solitary fultoportula bearing parentheses-like satellites. Scale bars: Figures $59,64=2 \mu \mathrm{m}$; Figures $60-63,65-66,68=1 \mu \mathrm{m}$; Figures $67,69=0.2 \mu \mathrm{m}$.

Table 3. Comparative valve measurements for T. mala recorded from the literature and the present study.

\begin{tabular}{|c|c|c|c|c|c|}
\hline & Valvar Diameter $(\mathrm{mm})$ & $\begin{array}{l}\text { Areolae in } 10 \mu \mathrm{m} \\
\quad \text { (center) }\end{array}$ & $\begin{array}{l}\text { Areolae in } 10 \mu \mathrm{m} \\
\quad(\text { margin })\end{array}$ & $\begin{array}{l}\text { Number of Fultoportulae } \\
\text { in } 10 \mu \mathrm{m}\end{array}$ & Striae Pattern \\
\hline Takano (1976) & $3.8-8.8$ & - & - & - & - \\
\hline Takano (1979) & $3-10$ & - & - & - & - \\
\hline Hallegraeff (1984) & $4-9$ & - & - & $7-9$ & Eccentric \\
\hline Licea (1990) & $5.2-7.2$ & $31-35$ & $47-51$ & - & Eccentric \\
\hline Hernández-Becerril et al. (1995) & $7-8$ & - & - & - & Irregular \\
\hline Aké-Castillo et al. (1999) & $5-6$ & 30 & $35-42$ & 10 & Radial $^{*}$ \\
\hline Sar et al. (2002) & $6-8$ & $25-35$ & $40-50$ & $10-14$ & Eccentric \\
\hline Fryxell \& Hasle (2003) & $2-20$ & $25-30$ & - & - & Radial \\
\hline This study & $3-12$ & 32 & $40-47$ & $9-14$ & Eccentric \\
\hline
\end{tabular}

*: Described as radial, but author's illustrations show fasciculate pattern sensu Johansen \& Fryxell (1985). 
To the south of our study area, T. mala and T. minuscula were already reported in Argentinean waters, reaching high density in late winter and early spring (Gayoso 1989; Ferrario \& Sar 1988; Sar et al. 2001; 2002; Vouilloud 2003). In our material from Paraná state, these species were abundant in late spring, when they comprised the main phytoplankton biomass. The spring maximum accompanied the overall intensive growth of diatoms due to the seasonal upwelling of SACW cold nutrient rich waters off Paraná coast from November to February (Brandini et al. 2006). Other authors also recorded an increase in diatom biomass during enrichment events, especially in spring and summer (e. g. Licea 1992; Aké-Castillo et al. 1999).

T. mala is a potentially harmful microalgae inhabiting coastal regions (Takano 1976). It presumably caused economical losses in Tokyo bay, Japan due to intense mucilage production and consequent obstruction of the filtering gills of oysters cultivated in marine farms (Takano 1956 as T. decipiens). Losses were estimated in 58 millions of yens at that time.

None of these species were reported in previous investigations (v. review of Moreira-Filho et al. 1990; Procopiak et al. 2006; Tremarin et al., 2008) in Paranaguá Bay, a large estuarine environment near the coastal shelf where our study was carried out. It might be that the lower salinity, ranging from 18 to 32, precluded the growth of the three species in the bay. Salinity in the adjacent coastal waters where our samples were collected ranged from 34 to 37 .

\section{Acknowledgements}

Many thanks are due to the organizers and lecturers of the APC 8 course (Advanced Phytoplankton Course, Naples, Italy), whose valuable teaching greatly benefited the first author. Special gratitude to Dr. G. R. Hasle, who elucidated important doubts on Thalassiosira morphology during the course, improving the manuscript. Project supported by FNMA (Fundo Nacional do Meio Ambiente), ALARME contract n. CVI 008/2002, and CNPq (Brazilian Research Council) under PADCT/CIAMB research project RAM n. 01/97-03/01-13. Dr. Frederico Brandini (UFPR) kindly provided the samples and environmental data for this study. E. F. S. benefited from a Master Dissertation CAPES grant, also sponsored by the Botany/UFPR graduate course. Two reviewers made valuable suggestions to the manuscript.

\section{References}

Aké-Castillo, J.A.; Hernández-Becerril, D.U. \& Meave Del Castillo, M.E. 1999. Species of the genus Thalassiosira (Bacillariophyceae) from the Gulf of Tehuantepec, México. Botanica Marina 42: 487-503.

Barber, H.G. \& Haworth, E.Y. 1981. A guide to the morphology of the diatom frustule. Freshwater Biological Association Scientific Publication 44: 1-112.

Brandini, F.P. 2006. Hidrografia e Produção Biológica na Região Sudeste-Sul do Brasil no Contexto do REVIZEE. Pp. 459-466. In:
Rossi-Wogtschowski, C.L.B.; Madureira, L.S.P. (Org.). O Ambiente Oceanográfico da Plataforma Continental e do Talude na Região Sudeste-Sul do Brasil. São Paulo, EDUSP.

Brandini, F.P. \& Fernandes, L.F. 1996. Microalgae of the continental shelf off Paraná state, southeastern Brazil: a review of studies. Revista Brasileira de Oceanografia 44(1): 69-80.

Brandini, F.P.; Lopes, R.M.; Gutseit, K.S.; Spach, H.L. \& Sassi, R. 1997. Planctonologia na plataforma continental do Brasil. Diagnose e revisão bibliográfica. Brasília, Ministério do Meio Ambiente/ CIRM/FEMAR.

Brandini, F.P.; Silva, E.T. \& Kolm, H.E. 2007. Sources of nutrients and seasonal dynamics of chlorophyll in the inner shelf off Paraná State - South Brazil Bight. Journal of Coastal Research 23: 200-226

Fernandes, L.F. \& Brandini, F.P. 2004. Diatom associations in shelf waters off Paraná, State, Southern Brazil: Annual variation in relation to environmental factors. Brazilian Journal of Oceanography 52(1): 19-34.

Ferrario, M.E. \& Sar, E.A. 1988. Marine Diatoms from Chubut (Argentina Republic) Centrales II - Thalassiosira. Revista Brasileira de Biologia 48(2): 421-429.

Ferrario, M.E. \& Galván, N.M. 1989. Catálogo de las diatomeas marinas citadas entre $\operatorname{los} 36^{\circ} \mathrm{y} \operatorname{los} 60^{\circ} \mathrm{S}$, con especial referencia al Mar Argentino. Instituto Antártico Argentino, Buenos Aires, n. 20, 327p.

Fryxell, G.A. \& Hasle, G.R. 2003. Marine Diatoms. In: Hallegraeff, G.M.; Anderson, D.M. \& Cembella, D.M. Manual on harmful marine microalgae. Paris, Intergovernmental Oceanographic Commission/ UNESCO.

Gayoso, A.M. 1989. Species of the diatom genus Thalassiosira from a coastal zone of the South Atlantic (Argentina). Botanica Marina 32: 331-337.

Garcia, M.A. \& Odebrecht, C. 2009a. Morphology and ecology of Thalassiosira Cleve (Bacillariophyta) species rarely recorded in Brazilian coastal waters. Revista Brasileiria de Biologia 69(4): 1059-1071.

Garcia, M.A. \& Odebrecht, C. 2009b. Chave dicotômica ilustrada para a identificação de espécies de Thalassiosira Cleve (diatomácea) no estuário da Lagoa dos Patos e área costeira adjacente (Rio Grande do Sul, Brasil). Biota Neotropica 9(2): 239-253.

Hallegraeff, G.M. 1984. Species of the diatom genus Thalassiosira in Australian waters. Botanica Marina 27: 495-513.

Hasle, G.R. 1972a. Two types of valve processes in centric diatoms. In: Simonsen (ed.), Proceedings on the First Symposium on Recent and Fossil Marine Diatoms. Nova Hedwigia 39: 55-77.

Hasle, G.R. 1972b. Thalassiosira subtilis (Bacillariophyceae) and two allied species. Norwegian Journal of Botany 19(2): 111-137.

Hasle, G.R. \& Fryxell, G.A. 1970. Diatoms: cleaning and mounting for light and electron microscopy. Transactions of the American Microscopical Society 84(4): 469-474.

Hasle, G.R. \& Syvertsen, E.E. Marine Diatoms. 1997. In: Tomas, C.R. (Ed.), Identifying Marine Phytoplankton. San Diego, Academic Press.

Helmcke, J.G. \& Krieger, W. 1953. Diatomeenschalen im elektronenmikroskopischen Bild I. Weinheim Cramer, 19p.

Helmcke, J.G. \& Krieger, W. 1954. Diatomeenschalen im elektronenmikroskopischen Bild II. Weinheim Cramer, 24p.

Hernández-Becerrill, D.U. \& Tapia-Peña, M.I. 1995. Planktonic diatoms from the Gulf of California and coasts off Baja California: species of the genus Thalassiosira. Botanica Marina 38: 543-555.

Herzig, W.N. \& Fryxell, G.A. 1986. The diatom genus Thalassiosira Cleve in Gulf Stream warm core rings: taxonomy, with T. intrannula and T. lineoides, spp. nov. Botanica Marina 29: 11-25.

Johansen, J.R. \& Fryxell, G.A., 1985. The genus Thalassiosira (Bacillariophyceae): studies on species occurring south of the Antarctic convergence zone. Phycologia 24: 155-179.

Lange, K.B. 1985. Spatial and seasonal variations of diatom assemblages off the Argentinian coast (South Western Atlantic). Oceanologica Acta 8(3): 361-370.

Lehmkuhl, E.A.; Tremarin, P.I.; Moreira-Filho, H. e Ludwig, T.A.V. 2010. Thalassiosirales (Diatomeae) da baía de Guaratuba, estado do Paraná, Brasil. Biota Neotropica 10: 313-324. 
Licea, S. 1992. Thalassiosira species from the Southern Gulf of Mexico. Pp. 311-335. In: Kociolek, J.P. (Ed.). Proceedings of the 11th International Diatom Symposium, San Francisco.

Mahood, A.D.; Fryxell, G.A. \& Mcmillan, M. 1986. The diatom genus Thalassiosira: species from the San Francisco Bay System. Proceedings of the California Academy of Sciences 44(8): 127-156.

Miyahara, K.; Nagai, S.; Itakura, S.; Yamamoto, K.; Fujisawa, K.; Iwamoto, T.; Yoshimatsu, S.; Matsuoka, S.; Yuasa, A.; Makino, K.; Hori, Y.; Nagata, S.; Nagasaki, K.; Yamaguchi, M. \& Honjo, T. 1996. First record of a Bloom of Thalassiosira diporocyclus in the Eastern Seto Inland Sea. Fisheries Science 62(6): 878-882.

Moreira-Filho, H.; Valente-Moreira, I.M. \& Souza-Mosimann, R.M.; Cunha, J.A. 1990. Avaliação florística e ecológica das Diatomáceas (Chrysophyta-Bacillariophyceae), marinhas e estuarinas nos estados do Paraná, Santa Catarina e Rio Grande do Sul. Estudos de Biologia 32: 5-48.

Olguin, H.F.; Boltovskoy, D.; Lange, C.B. \& Brandini, F. 2006. Distribution of spring phytoplankton (mainly diatoms) in the upper $50 \mathrm{~m}$ of the Southwestern Atlantic Ocean $\left(30^{\circ}-61^{\circ} \mathrm{S}\right)$. Journal of Plankton Research 28(12): 1107-128.

Procopiak, L.K.; Fernandes. L.F. \& Moreira-Filho, H. 2006. Diatomáceas (Bacillariophyta) marinhas estuarinas do Paraná, Sul do Brasil: lista de espécies com ênfase em espécies nocivas. Biota Neotropica 6(3): $1-28$.

Rivera, R.P. 1981. Beiträge zur Taxonomie und Verbreitung der Gattung Thalassiosira Cleve (Bacillariophyceae) in den Küstengewässern Chile. Bibliotheca Phycologica, Stuttgart, vol. 56, 225p

Round, F.E.; Crawford, R.M. \& Mann, D.G. 1990. The diatoms. Biology and morphology of the genera. Cambridge, Cambridge Press.
Sar, E.A. 1996. Flora diatomológica de la Bahía San Antonio (Prov. de Río Negro, Argentina). O. Centrales I. Revista del Museo de La Plata 14(106):365-400.

Sar, E.A.; Sunesen, I. \& Castaños, C. 2001. Marine diatoms from Buenos Aires coastal waters (República Argentina) I Thalassiosiraceae. Nova Hedwigia 73: 199-228.

Sar, E.A; Sunesen, I. \& Lavigne, A.S. 2002. The diatom genus Thalassiosira: species from the northern San Matías Gulf (Rio Negro, Argentina). Nova Hedwigia 74: 373-386.

Takano, H. 1956. Harmful blooming of minute cells of Thalassiosira decipiens in coastal water in Tokyo Bay. Journal of Oceanographical Society of Japan 12: 63-67.

Takano, H. 1976. Scanning electron microscopy of diatoms - II. Bulletin of Tokai Regional Fisheries Research Laboratory 87: 57-65.

Takano, H. 1979. Synopsis of red-tide organisms. Working party on taxonomy in the akashiwo kenkyukai c/c fisheries, Tokyo, n. 1-90.

Takano, H. 1990. Diatoms. In "Red tide organisms in Japan-An illustrated taxonomic guide”. (Y. Fukuyo, H. Takano, M. Chihara \& K. Matsuoka eds). Uchida Rokakuho, Tokyo, p. 162-331.

Tremarin, P.I, Ludwig, T.A.V \& Moreira-Filho, H.M. 2008. Thalassiosirales (Diatomeae) da Baía de Guaratuba, Estado do Paraná, Brasil Acta Botanica Brasilica 22: 1101-1113.

Torgan, L.C. \& Santos, C.B. 2006. Thalassiosira weissflogii (Coscinodiscophyceae, Bacillariophyta) em ambientes lacustres na planície costeira do sul do Brasil. Iheringia, Serie Botânica 61: 135-138.

Torgan, L.C. \& Santos, C.B. 2007. Ocorrência de Thalassiosira nodulolineata (Bacillariophyta) na Laguna dos Patos, Brasil. Revista Brasileira de Biociências 5: 714-716.

Vouilloud, A.A. 2003. Catalogo de diatomeas continentales y marinas argentinas. CD, not paginated, La Plata, ISBN 987-21041-0-7. 